\title{
Notulae to the Italian alien vascular flora: II
}

Gabriele Galasso', Gianniantonio Domina ${ }^{2}$, Sebastiano Andreatta ${ }^{3}$, Emmanuelle Argenti ${ }^{4}$, Gianluigi Bacchetta ${ }^{5}$, Simonetta Bagella ${ }^{6}$, Enrico Banfi ${ }^{1}$, Davide Barberis ${ }^{7}$, Serlapo Bardi ${ }^{8}$, Giulio Barone ${ }^{2}$, Fabrizio Bartolucci ${ }^{9}$, Alessio Bertolli ${ }^{10}$, Nello Biscotti ${ }^{11}$, Fabrizio Bonali ${ }^{12}$, Federica Bonini ${ }^{13}$, Daniele Bonsanto ${ }^{11}$, Giuseppe Brundu ${ }^{14}$, Sergio Buono ${ }^{15}$, Orazio Caldarella ${ }^{16}$, Giacomo Calvia ${ }^{5}$, Salvatore Cambria ${ }^{17}$, Giuliano Campus ${ }^{18}$, Maria C. Caria ${ }^{19}$, Fabio Conti ${ }^{9}$, Andrea Coppi ${ }^{20}$, Davide Dagnino ${ }^{21}$, Emanuele Del Guacchio $^{22}$, Emilio Di Gristina ${ }^{2}$, Emmanuele Farris ${ }^{6}$, Giulio Ferretti ${ }^{20}$, Francesco Festi ${ }^{10}$, Mauro Fois ${ }^{5}$, Fabrizio Furlani ${ }^{23}$, Daniela Gigante ${ }^{13}$, Riccardo Guarino ${ }^{24}$, Leonardo Gubellini25 ${ }^{25}$ Nicole Hofmann ${ }^{\prime \prime}$, Duilio Iamonico ${ }^{26}$, Pedro Jiménez-Mejías ${ }^{27,28}$, Alfonso La Rosa ${ }^{29}$, Valentina L. A. Laface ${ }^{30}$, Andrea Lallai ${ }^{5}$, Lorenzo Lazzaro ${ }^{20}$, Michele Lonati ${ }^{7}$, Vanessa Lozano $^{14}$, Fabio Luchino ${ }^{31}$, Jacopo Lupoletti ${ }^{32}$, Sara Magrini ${ }^{33}$, Andrea Mainetti ${ }^{7}$, Dino Marchetti ${ }^{34}$, Paolo Marenzi ${ }^{35}$, Michela Marignani ${ }^{5}$, Marco Martignoni ${ }^{36}$, Giacomo Mei ${ }^{11}$, Flavio Menini ${ }^{37}$, Marco Merli ${ }^{38}$, Michele Mugnai ${ }^{20}$, Carmelo M. Musarella ${ }^{30}$, Gianluca Nicolella ${ }^{39}$, Amara Noor Hussain ${ }^{40}$, Nicola Olivieri ${ }^{41}$, Stefano Orlandini ${ }^{11}$,

Simonetta Peccenini ${ }^{21}$, Lorenzo Peruzzi ${ }^{42}$, Antonio Pica ${ }^{43}, \mathrm{Nicola} \mathrm{Pilon}^{44}$, Lorenzo Pinzani ${ }^{42}$, Marco Pittarello ${ }^{7}$, Lina Podda ${ }^{5}$, Massimiliano Probo ${ }^{45}$, Filippo Prosser ${ }^{10}$, Claudio Raffaelli ${ }^{10}$, Simone Ravetto Enri ${ }^{7}$, Giovanni Rivieccio ${ }^{19}$,

Leonardo Rosati $^{46}$, Simona Sarmati ${ }^{47}$, Filippo Scafidi ${ }^{2}$, Federico Selvi ${ }^{48}$, Alexander N. Sennikov ${ }^{49,50}$, Giovanna Sotgiu Cocco $^{8}$, Giovanni Spampinato ${ }^{30}$, Adriano Stinca ${ }^{51}$, Gianmarco Tavilla ${ }^{17}$, Valeria Tomaselli ${ }^{52}$, Davide Tomasi ${ }^{53}$,

Giulia Tomasi ${ }^{10}$, Maurizio Trenchi ${ }^{54}$, Claudia Turcato ${ }^{55}$, Filip Verloove ${ }^{56}$, Daniele Viciani ${ }^{20}$, Milena Villa ${ }^{57}$, Robert P. Wagensommer ${ }^{52}$, Lorenzo Lastrucci ${ }^{58}$

I Sezione di Botanica, Museo di Storia Naturale di Milano, Corso Venezia 55, 20121, Milano, Italy 2 Dipartimento di Scienze Agrarie, Alimentari e Forestali (SAAF), Università di Palermo, Viale delle Scienze, edificio 4, 90128, Palermo, Italy 3 Museo Civico di Storia Naturale di Verona, Piazza Arsenale 8, 37126, Verona, Italy 4 Parco Naturale Regionale di Bracciano-Martignano, Via A. Saffi 4la, 00062, Bracciano (Roma), Italy 5 Dipartimento di Scienze della Vita e dell'Ambiente, Università di Cagliari, Viale Sant'Ignazio da Laconi 13, 09123, Cagliari, Italy 6 Dipartimento di Chimica e Farmacia, Università di Sassari, Via Piandanna 4, 07100, Sassari, Italy 7 Dipartimento di Scienze Agrarie, Forestali e Alimentari (DISAFA), Università di Torino, Largo P. Braccini 2, 10095, Grugliasco (Torino), Italy 8 Via V. Hugo 6, 09014, Carloforte (Sud Sarde-

Copyright Gabriele Galasso et al. This is an open access article distributed under the terms of the Creative Commons Attribution License (CC BY 4.0), which permits unrestricted use, distribution, and reproduction in any medium, provided the original author and source are credited. 
gna), Italy 9 Centro Ricerche Floristiche dell'Appennino (Università di Camerino - Parco Nazionale del Gran Sasso e Monti della Laga), San Colombo, 67021, Barisciano (L'Aquila), Italy 10 Fondazione Museo Civico di Rovereto, Largo Santa Caterina 41, 38068, Rovereto (Trento), Italy II Dipartimento di Scienze Agrarie, Alimentari ed Ambientali (D3A), Università Politecnica delle Marche, Via Brecce Bianche 10, 60131, Ancona, Italy 12 Via G. Carnevali 2, 26100, Cremona, Italy 13 Dipartimento di Scienze Agrarie, Alimentari e Ambientali (DSA3), Università di Perugia, Borgo XX Giugno 74, 06121, Perugia, Italy 14 Dipartimento di Agraria, Università di Sassari, Viale Italia 39, 07100, Sassari, Italy 15 Via XXV Aprile 6, 01010, Oriolo Romano (Viterbo), Italy 16 Viale Maria Santissima Mediatrice 38, 90129, Palermo, Italy 17 Dipartimento di Scienze Biologiche, Geologiche e Ambientali, Università di Catania, Via A. Longo 19, 95125, Catania, Italy 18 Via G. Rossini 69, 09045, Quartu Sant'Elena (Cagliari), Italy 19 Nucleo di Ricerca sulla Desertificazione, Università di Sassari, Via E. de Nicola snc, 07100, Sassari, Italy 20 Dipartimento di Biologia, Università di Firenze, Via G. La Pira 4, 50121, Firenze, Italy 2 I Dipartimento di Scienze della Terra, dell'Ambiente e della Vita (DISTAV), Università di Genova, Corso Europa 26, 16132, Genova, Italy 22 Orto Botanico di Napoli, Università di Napoli Federico II, Via Foria 223, 80139, Napoli, Italy 23 Via A. Labriola 19, 61122, Pesaro (Pesaro e Urbino), Italy 24 Dipartimento di Scienze e Tecnologie Biologiche, Chimiche e Farmaceutiche (STEBICEF), Università di Palermo, Via Archirafi 20, 90123, Palermo, Italy 25 Centro Ricerche Floristiche Marche, Provincia di Pesaro e Urbino, Via E. Barsanti 18, 61122, Pesaro (Pesaro e Urbino), Italy 26 Dipartimento di Pianificazione, Design, Tecnologia dell'Architettura (PDTA), Sapienza Università di Roma, Via Flaminia 72, 00196, Roma, Italy 27 Centro de Investigación en Biodiversidad y Cambio Global (CIBC-UAM), Universidad Autónoma de Madrid, 28049, Madrid, Spain 28 Departamento de Biología (Botánica), Facultad de Ciencias Biológicas, Universidad Autónoma de Madrid, C/ Darwin 2, 28049, Madrid, Spain 29 Cooperativa Silene a r.l., Via V. D’Ondes Reggio Vito 8/a, 90127, Palermo, Italy 30 Dipartimento di Agraria, Università Mediterranea di Reggio Calabria, Località Feo di Vito snc, 89122, Reggio Calabria, Italy 3 I Via Torrente Allume 6la, 98027, Roccalumera (Messina), Italy 32 Viale A. Moro 76, 64032, Atri (Teramo), Italy 33 Banca del Germoplasma della Tuscia, Università della Tuscia, Largo dell'Università snc, blocco c, 01100, Viterbo, Italy 34 Via Isonzo 6, 54100, Massa (Massa-Carrara), Italy 35 Via Sebenico 19, 26040, Bonemerse (Cremona), Italy 36 Piazza G. Matteotti 25, 21050, Lonate Ceppino (Varese), Italy 37 Via D. Ricci 4, 37042, Caldiero (Verona), Italy 38 Via dei Caputei 7, 38070, Stenico, fraz. Sclemo (Trento), Italy 39 Via di Valle Melaina 61, 00139, Roma, Italy 40 Dipartimento di Bioscienze e Territorio, Università del Molise, Contrada Fonte Lappone, 86090, Pesche (Isernia), Italy 4I Via Maestri del Lavoro 40, 64100, Teramo, Italy 42 Dipartimento di Biologia, Università di Pisa, Via Derna 1, 56126, Pisa, Italy 43 Via Strada Storta 11, 66100, Chieti, Italy 44 Elitron, Via Capri 11/3, 20153, Milano, Italy 45 Grazing Systems, Agroscope, Route de Duillier 50, 1260, Nyon, Switzerland 46 Scuola di Scienze Agrarie, Forestali e Ambientali, Università della Basilicata, Via Ateneo Lucano 10, 85100, Potenza, Italy 47 Dipartimento di Scienze della Vita, Università di Siena, Via P.A. Mattioli 4, 53100, Siena, Italy 48 Dipartimento di Scienze e Tecnologie Agrarie, Alimentari, Ambientali e Forestali, Università di Firenze, Piazzale delle Cascine 28, 50144, Firenze, Italy 49 Botanical Museum, Finnish Museum of Natural History, University of Helsinki, P.O. Box 7, FI-00014, Helsinki, Finland $\mathbf{5 0}$ Komarov Botanical Institute of Russian Academy of Sciences, Prof. Popov Str. 2, RU-197376, St. Petersburg, Russia 5 I Dipartimento di Scienze e Tecnologie Ambientali, Biologiche e Farmaceutiche, Università della Campania Luigi Vanvitelli, Via A. Vivaldi 43, 81100, Caserta, Italy 52 Dipartimento di Biologia, Università di Bari Aldo Moro, Via E. Orabona 4, 70125, Bari, Italy 53 Viale Venezia 6, 36073, Cornedo Vicentino (Vicenza), Italy 54 Via Villa Cozza 24, 37131, Verona, Italy 55 Ce.S.Bi.N s.r.l., Via San Vincenzo 2, 16121, Genova, Italy 56 Botanic Garden of Meise, Nieuwelaan 38, 1860, Meise, Belgium 57 Via Lauro 4, 23888, La Valletta Brianza (Lecco), Italy 58 Sistema Museale di Ateneo, Università di Firenze, Via G. La Pira 4, 50121, Firenze, Italy 
Academic editor: Stefania Biondi | Received 29 April 2021 | Accepted 12 May 2021 | Published 21 May 2021

Citation: Galasso G, Domina G, Andreatta S, Argenti E, Bacchetta G, Bagella S, Banfi E, Barberis D, Bardi S, Barone G, Bartolucci F, Bertolli A, Biscotti N, Bonali F, Bonini F, Bonsanto D, Brundu G, Buono S, Caldarella O, Calvia G, Cambria S, Campus G, Caria MC, Conti F, Coppi A, Dagnino D, Del Guacchio E, Di Gristina E, Farris E, Ferretti G, Festi F, Fois M, Furlani F, Gigante D, Guarino R, Gubellini L, Hofmann N, Iamonico D, Jiménez-Mejías P, La Rosa A, Laface VLA, Lallai A, Lazzaro L, Lonati M, Lozano V, Luchino F, Lupoletti J, Magrini S, Mainetti A, Marchetti D, Marenzi P, Marignani M, Martignoni M, Mei G, Menini F, Merli M, Mugnai M, Musarella CM, Nicolella G, Noor Hussain A, Olivieri N, Orlandini S, Peccenini S, Peruzzi L, Pica A, Pilon N, Pinzani L, Pittarello M, Podda L, Probo M, Prosser F, Raffaelli C, Ravetto Enri S, Rivieccio G, Rosati L, Sarmati S, Scafidi F, Selvi F, Sennikov AN, Sotgiu Cocco G, Spampinato G, Stinca A, Tavilla G, Tomaselli V, Tomasi D, Tomasi G, Trenchi M, Turcato C, Verloove F, Viciani D, Villa M, Wagensommer RP, Lastrucci L (2021) Notulae to the Italian alien vascular flora: 11. Italian Botanist 11: 93-119. https://doi.org/10.3897/italianbotanist.11.68063

\section{Abstract}

In this contribution, new data concerning the distribution of vascular flora alien to Italy are presented. It includes new records, confirmations, exclusions, and status changes for Italy or for Italian administrative regions. Nomenclatural and distribution updates published elsewhere are provided as Suppl. material 1.

\section{Keywords}

Alien species, floristic data, Italy, nomenclature

\section{How to contribute}

The text for the new records should be submitted electronically to Lorenzo Lastrucci (lorenzo.lastrucci@unifi.it). The corresponding specimen along with its scan or photograph has to be sent to FI Herbarium: Museo di Storia Naturale (Botanica), Sistema Museale di Ateneo, Via G. La Pira 4, 50121 Firenze (Italy). Those texts concerning nomenclatural novelties (typifications only for accepted names), status changes, exclusions, and confirmations should be submitted electronically to Gabriele Galasso (gabriele.galasso@comune.milano.it).Each text should be within 1,000 characters (spaces included).

\section{Floristic records}

\section{Acacia dealbata Link (Fabaceae)}

+ (NAT) SIC: Castelbuono (Palermo), c.da Vicaretto (WGS84: $37.901537^{\circ} \mathrm{N}$, $14.125820^{\circ} \mathrm{E}$ ), pascolo abbandonato, 7 July 2018, G. Domina (SAF); Cefalù (Palermo), c.da Carbonara (WGS84: $38.005208^{\circ} \mathrm{N}, 14.027224^{\circ} \mathrm{E}$ ), vicinanze di oliveto e frutteti, 580 m, 8 August 2020, G. Domina (FI, SAF). - Naturalized alien species new for the flora of Sicilia. 
Several individuals originating from seeds produced by nearby trees were observed at different growth stages.

F. Scafidi, G. Barone, E. Di Gristina

\section{Acalypha australis L. (Euphorbiaceae)}

+ (NAT) VEN: Sommacampagna (Verona), a SW di Sommacampagna, loc. Balconi Rossi (WGS84: $45.395550^{\circ} \mathrm{N}, 10.807802^{\circ} \mathrm{E}$ ), campo di mais, $107 \mathrm{~m}, 22$ October 2020, F. Prosser, G. Tomasi, M. Gecchelin (ROV); Valeggio sul Mincio (Verona), a NW di Valeggio sul Mincio presso Ca' Forneletti (WGS84: $45.373276^{\circ} \mathrm{N}, 10.711337^{\circ} \mathrm{E}$ ), campi di mais e zucchine, 65 m, 23 October 2020, A. Bertolli, F. Festi (ROV); Castel d'Azzano (Verona) (WGS84: 45.355930 N, 10.942225 $\mathrm{E}$ ), aiuola incolta, $46 \mathrm{~m}, 27$ October 2020, F. Prosser, G. Tomasi, M. Gecchelin (FI, ROV); Sona (Verona), fraz. San Giorgio in Salici (WGS84: $45.42800998^{\circ} \mathrm{N}, 10.79159430^{\circ} \mathrm{E}$ ), margine vigneto, 30 October 2020, A. Bertolli, F. Festi, M. Gecchelin (ROV). - Naturalized alien species new for the flora of Veneto.

In Veneto, this species was found in the western part close to the border with Lombardia (Ca' Forneletti); in this site, the species' occurrence is widespread, thereby becoming a dangerous weed.

A. Bertolli, F. Festi, F. Prosser, G. Tomasi

\section{Acer saccharinum L. subsp. saccharinum (Sapindaceae)}

+ (CAS) LIG: Carasco (Genova), ZSC “IT1332717 Foce e medio corso del Fiume Entella”, loc. San Quirico, riva sinistra (WGS84: $44.35271^{\circ} \mathrm{N}, 9.35779^{\circ} \mathrm{E}$ ), bosco ripario di salici e pioppi (Habitat Natura 2000 cod. 92A0), 19 m, 23 July 2020, leg. D. Dagnino, C. Turcato, det. E. Banfi, D. Dagnino, C. Turcato (FI, GE No. 2693). Casual alien species new for the flora of Liguria.

D. Dagnino, C. Turcato, E. Banfi

\section{Actinidia deliciosa (A.Chev.) C.F.Liang \& A.R.Ferguson (Actinidiaceae)}

+ (CAS) PIE: Vistrorio (Torino), loc. Ciapies, bosco ripariale in sinistra orografica del Torrente Chiusella (WGS84: $45.442472^{\circ} \mathrm{N}, 7.759771^{\circ} \mathrm{E}$ ), bosco ripariale, $465 \mathrm{~m}, 12$ June 2020, S. Ravetto Enri, A. Mainetti, D. Barberis (FI); Rueglio (Torino), scarpata a monte della Strada per Bossola (WGS84: $45.477199^{\circ} \mathrm{N}, 7.763217^{\circ} \mathrm{E}$ ), castagneto ceduo, 650 m, 26 September 2020, S. Ravetto Enri (FI). - Casual alien species new for the flora of Piemonte.

Two individuals were found in the above-mentioned sites: a well-developed fruiting female individual climbing along a $5 \mathrm{~m}$ tall Salix alba L. and a young male individual $c a .1 \mathrm{~m}$ tall. 


\section{Ajuga dictyocarpa Hayata (Lamiaceae)}

+ (CAS) ITALIA (LOM): Milano (Milano), Via C. Valvassori Peroni (WGS84: ca. $45.480805^{\circ} \mathrm{N}, 9.236509^{\circ} \mathrm{E}$ ), casuale in un vaso di ligustro, $116 \mathrm{~m}, \mathrm{~W}, 15$ May 2020, E. Banfi (FI, MSNM No. 50727). - Casual alien species new for the flora of Italy (Lombardia).

This species, native to East Asia, was identified with Flora of China ( $\mathrm{Li}$ and Hedge 1994).

E. Banfi, G. Galasso

\section{Alcea biennis Winterl subsp. biennis (Malvaceae)}

+ (CAS) CAL: Reggio Calabria (Reggio Calabria), Piani di San Nicola, fraz. Ortì (WGS84: $38.152106^{\circ} \mathrm{N}, 15.695742^{\circ} \mathrm{E}$ ), bordo strada, $559 \mathrm{~m}, 29$ June 2020, leg. V.L.A. Laface, det. V.L.A. Laface, C.M. Musarella, G. Spampinato (FI). - Casual alien species new for the flora of Calabria.

The recorded individuals originated from seeds of plants cultivated in a nearby monastery for medicinal purposes.

C.M. Musarella, V.L.A. Laface, G. Spampinato

\section{Allium tuberosum Rottler ex Spreng. (Amaryllidaceae)}

+ (NAT) TOS: Anghiari (Arezzo), lungo la strada SS73 Senese-Aretina (E78) al km 172 (WGS84: $43.511004^{\circ} \mathrm{N}, 12.084579^{\circ} \mathrm{E}$ ), erbosi ai margini della strada, $313 \mathrm{~m}, 22$ September 2020, F. Selvi, L. Lazzaro, A. Coppi (FI). - Naturalized alien species new for the flora of Toscana.

Allium tuberosum is native to Asia, but is nowadays widely cultivated for ornamental and culinary purposes (Blattner and Friesen 2006). We observed several flowering individuals forming a well-established population at the edge of the road SS73 (from $\mathrm{km} 170$ to 172). We also observed a few other individuals along the same road between Le Lastre and Arezzo at km 147 (WGS84: $43.424812^{\circ} \mathrm{N}, 11.920076^{\circ} \mathrm{E}$ ).

F. Selvi, L. Lazzaro, A. Coppi

\section{Amaranthus muricatus (Moq.) Gillies ex Hieron. (Amaranthaceae)}

+ (NAT) LAZ: Roma (Roma), Via Monte Ruggero (WGS84: $41.948146^{\circ} \mathrm{N}$, $12.529498^{\circ} \mathrm{E}$ ), marciapiede, $30 \mathrm{~m}, 28$ November 2017, G. Nicolella (RO); ibidem, 15 July 2020, D. Iamonico, G. Nicolella (HFLA, RO); ibidem, Via Sarandi (WGS84: $41.948286^{\circ} \mathrm{N}, 12.529817^{\circ} \mathrm{E}$ ), marciapiede, $39 \mathrm{~m}, 15$ July 2020, D. Iamonico, G. Nicolella (HFLA, RO); ibidem, Via Monte Cardoneto (WGS84: $41.947950^{\circ} \mathrm{N}$, $12.529648^{\circ}$ E), terrapieno, 28 September 2020, G. Nicolella (HFLA, RO). - Status change from casual to naturalized alien for the flora of Lazio. 
Amaranthus muricatus was observed for the first time in Roma in 2017 as a casual alien (Nicolella 2018). In recent years, we noticed that this species regularly produces abundant fruits. Despite recurrent cuts, it still occurs in the place of first discovery and has also spread to some nearby streets.

D. Iamonico, G. Nicolella, A. Noor Hussain

\section{Amaranthus palmeri S. Watson (Amaranthaceae)}

+ (NAT) MAR: Fano (Pesaro e Urbino), sponda destra del Fiume Metauro, poco a monte del ponte autostradale (WGS84: $43.8108333^{\circ} \mathrm{N}, 13.0391666^{\circ} \mathrm{E}$ ), greto fluviale ghiaioso, ca. 5 m, 8 October 2020, L. Gubellini (FI, PESA). - Naturalized alien species new for the flora of Marche.

A few individuals were observed growing in the stony riverbed of the Metauro river about $4 \mathrm{~km}$ from its mouth.

L. Gubellini, N. Hofmann

\section{Asparagus aethiopicus L. (Asparagaceae)}

+ (CAS) CAL: Reggio Calabria (Reggio Calabria), Via G. De Nava (WGS84: $38.119775^{\circ} \mathrm{N}, 15.653339^{\circ} \mathrm{E}$ ), marciapiedi, $18 \mathrm{~m}, 22$ September 2020, V.L.A. Laface, C.M. Musarella, G. Spampinato (FI, REGGIO). - Casual alien species new for the flora of Calabria.

Only two individuals were found growing in a crack in the sidewalk, probably escaped from the balconies of nearby houses.

C.M. Musarella, V.L.A. Laface, G. Spampinato

\section{Begonia grandis Dryand. subsp. grandis (Begoniaceae)}

+ (CAS) SIC: Palermo (Palermo), Via G. Malvica, nei pressi del civico 24 (WGS84: $38.1292592^{\circ} \mathrm{N}, 13.3504172^{\circ} \mathrm{E}$ ), negli interstizi dei marciapiedi, 15 July 2020, E. Di Gristina (FI). - Casual alien species new for the flora of Sicilia.

Some mature individuals of this cultivated perennial native to Japan were found in the interstices of the sidewalks, probably coming from nearby adult fruiting plants.

E. Di Gristina, F. Scafidi, G. Barone

\section{Bidens subalternans DC. (Asteraceae)}

+ (NAT) TAA: Rovereto (Trento), riva sinistra del Fiume Adige a monte del ponte di Villa Lagarina (WGS84: $45.918331^{\circ} \mathrm{N}, 11.046048^{\circ} \mathrm{E}$ ), un esemplare, $174 \mathrm{~m}, 19$ September 2019, leg. C. Raffaelli, det. F. Prosser (ROV); Ala (Trento), sponda destra del Fiume Adige presso Chizzola (WGS84: $45.80800950^{\circ} \mathrm{N}, 11.01131898^{\circ} \mathrm{E}$ ), una decina di esemplari, 146 m, 20 July 2020, leg. A. Bertolli, G. Tomasi, det. F. Prosser (ROV); Trento (Trento), riva destra del Fiume Adige di fronte alla loc. Acquaviva (WGS84: 
$45.98892636^{\circ} \mathrm{N}, 11.11568431^{\circ} \mathrm{E}$ ), un migliaio di esemplari per un tratto di ca. $1 \mathrm{~km}$, 186-187 m, 6 October 2020, C. Raffaelli (FI, ROV). - Naturalized alien species new for the flora of Trentino-Alto Adige.

In Trentino, this species is spreading along the Adige river, probably starting from the vast settlement near Acquaviva, thanks to the transport of sheep. This is confirmed by a further observation, again along the Adige, just south of Avio (WGS84: $\left.45.720804^{\circ} \mathrm{N}, 10.936019^{\circ} \mathrm{E}\right)$.

C. Raffaelli, A. Bertolli, G. Tomasi, F. Prosser

\section{Bidens vulgata Greene (Asteraceae)}

+ (NAT) VEN: Verona (Verona), Porto San Pancrazio (WGS84: 45.431196º N, $11.020334^{\circ} \mathrm{E}$ ), diversi esemplari in fiore sulla sponda di un fossato, $42 \mathrm{~m}, 6$ October 2020, S. Andreatta (FI, VER No. SA459). - Naturalized alien species new for the flora of Veneto.

Until recently, this species has been misidentified with Bidens frondosa L. (Veerlove and Ardenghi 2015; Galasso et al. 2016). During field surveys in 2020, we also observed consistent populations of this taxon in other localities, such as San Bonifacio (Verona, WGS84: $45.40250^{\circ} \mathrm{N}, 11.25814^{\circ} \mathrm{E}$ ), Cerea (Verona, WGS84: $45.199084^{\circ} \mathrm{N}$, $\left.11.203187^{\circ} \mathrm{E}\right)$, San Martino Buon Albergo (Verona).

F. Menini, M. Trenchi, S. Andreatta

\section{Bothriochloa saccharoides (Sw.) Rydb. subsp. saccharoides (Poaceae)}

+ (NAT) ITALIA (VEN): Thiene (Vicenza), Via del Terziario SP349, nelle aree contermini all'ipermercato (WGS84: $45.6933378^{\circ} \mathrm{N}, 11.4826360^{\circ} \mathrm{E}$ ), migliaia di esemplari distribuiti sul bordo strada, nelle scarpate stradali, negli incolti erbosi, $124 \mathrm{~m}$, no exp., 21 September 2019, leg. D. Tomasi, det. A.S. Vega (FI, MSNM Nos. 50878, 50879, Herb. D. Tomasi). - Naturalized alien species new for the flora of Italy (Veneto).

Bothriochloa saccharoides is a grass native to the American continent (Vega 2000). The systematics of the $B$. saccharoides complex is quite complex. Indeed, this species had already been previously reported in Italy for western Liguria by Barberis and Orsino (1984), but later the record was attributed to B. laguroides (DC.) Herter subsp. laguroides (Verloove and Lambonon 2008; Galasso et al. 2018). A similar report for France was, instead, attributed to B. barbinoidis (Lag.) Herter (Lambinon 1995), so this record is the first for Europe. The discovery site consists of a large area of $c a .100 \mathrm{~m}$ in radius characterized by a herbaceous cenosis, in which $B$. saccharoides is dominant.

D. Tomasi

\section{Bougainvillea glabra Choisy (Nyctaginaceae)}

+ (CAS) ITALIA (TOS): Vecchiano (Pisa), Tenuta di Migliarino, vicino al confine con Torre del Lago, all'interno della ZSC “IT5170001 Dune litoranee di Torre del Lago", 
nella parte litoranea della Tenuta (WGS84: $43.8124^{\circ} \mathrm{N}, 10.2626^{\circ} \mathrm{E}$ ), zone retrodunali con aree aperte, alberi e arbusti sparsi, 20 June 2018, D. Viciani, S. Sarmati (FI). Casual alien species new for the flora of Italy (Toscana).

Bougainvillea glabra is an ornamental vine, very similar to B. spectabilis Willd. from which it differs for leaves glabrous to sparsely pubescent, generally elliptical with acute to attenuate base ( $v s$ usually densely pubescent, ovate with obtuse to rounded base), and for branches with generally straight ( $v$ recurve) spines (Lu and Gilbert 2003; Udulutsch et al. 2020). We observed a wild individual in a seemingly little disturbed dune environment.

D. Viciani, S. Sarmati, G. Ferretti

\section{Bulbine asphodeloides (L.) Spreng. (Asphodelaceae)}

+ (CAS) TOS: Massarosa (Lucca), Via Padule in Quiesa (WGS84: $43.838382^{\circ} \mathrm{N}$, $10.355687^{\circ} \mathrm{E}$ ), scarpata su muro a bordo strada, in espansione, $20 \mathrm{~m}, 16$ January 2021 , L. Pinzani (FI, Herb. L. Pinzani). - Casual alien species new for the flora of Toscana.

L. Pinzani

\section{Carex tribuloides Wahlenb. (Cyperaceae)}

+ (NAT) ITALIA (LOM): Arsago Seprio (Varese), ZSC "IT2010011 Paludi di Arsago", Palude Pollini (WGS84: $45.69967^{\circ} \mathrm{N}, 8.72270^{\circ} \mathrm{E}$ ), sponde di stagno periodicamente inondate, 293 m, no exp., 31 May 2020, leg. M. Martignoni, N. Pilon, det. P. Jiménez-Mejías, conf. A. Hipp, A.A. Reznicek (FI, MSNM No. 50819, UPOS); ibidem, 20 June 2020, leg. M. Martignoni, N. Pilon, det. P. Jiménez-Mejías, conf. A. Hipp, A.A. Reznicek (MSNM No. 50820, UPOS). - Naturalized alien species new for the flora of Italy (Lombardia).

Carex tribuloides is native to eastern North America, where it inhabits wet to moist open habitats. It belongs to the species-rich section Cyperoideae G.Don, including 3 species in Europe and $c a .90$ species in North America. It can be confused with two other North American relatives that are also introduced in Europe, C. bebbii (L.H.Bailey) Fernald and C. scoparia Willd., from which it can be easily distinguished (Mastrogiuseppe et al. 2002) by the leaf sheaths (apex expanded upwards beyond the insertion of the blade $v$ s truncate) and the utricles (wingless or very narrowly winged towards the base $v s$ conspicuously winged towards the base). C. tribuloides was previously reported from Sweden, from where it seems to have disappeared (Wallnöfer and Essl 2016). Two large tufts of about $1 \mathrm{~m}^{2}$ were observed.

M. Martignoni, N. Pilon, G. Galasso, P. Jiménez-Mejías

\section{Chamaecyparis lawsoniana (A.Murray) Parl. (Cupressaceae)}

+ (CAS) ABR: Campli (Teramo), loc. Battaglia, zona Pianevie, nella vallata del Torrente Fosso Grande (WGS84: 42.704166 $\mathrm{N}, 13.618888^{\circ} \mathrm{E}$ ), orlo di vegetazione 
boschiva, ca. 720 m, N, 4 October 2020, N. Olivieri (FI). - Casual alien species new for the flora of Abruzzo.

Some young individuals of the species grow in a cool and shady area located at the bottom of a narrow valley subjected to thermal inversion, where the soil is a calcareous rendzina. The plants originated from seeds produced by a nearby artificial reforestation area.

N. Olivieri

\section{Chasmanthe aethiopica (L.) N.E.Br. (Iridaceae)}

- TOS. - Alien species to be excluded from the flora of Toscana.

According to literature data, the presence of this species in Toscana has been reported for the Tuscan Archipelago and for Monte Argentario (Baldini 1995). In the Tuscan Archipelago, it was first reported by Sommier (1900), based on specimens collected on the islands of Capraia (FI!) and Elba (FI!). Subsequently, it was confirmed for both islands (Lastrucci et al. 2012a; Lazzaro et al. 2014). A further report for the island of Gorgona (Arrigoni 2017) lacks herbarium documentation in FI. A review, based on de Vos (1985), Grandis (2016), and Lazzeri (2016), of all herbarium material preserved in FI for Toscana and linked to the records cited above, has allowed us to attribute all the specimens to Chasmanthe floribunda (Salisb.) N.E.Br. (Tuscan Archipelago) or to C. bicolor (Gasp.) N.E.Br. (Monte Argentario).

G. Ferretti, L. Lazzaro

\section{Chasmanthe floribunda (Salisb.) N.E.Br. (Iridaceae)}

+ (NAT) TOS. - Alien status indication for the flora of Toscana.

On the basis of the previous records wrongly referred as to Casmanthe aethiopica (L.) N.E.Br., C. floribunda should be considered as naturalized in Toscana.

G. Ferretti, L. Lazzaro

+ (INV) ITALIA (SAR). - Status change from casual to invasive alien for the flora of Italy (Sardegna).

In recent years, this species has become invasive in several semi-natural habitats, such as fallows, abandoned vineyards, reforested areas, rivers banks, and road margins. It is particularly invasive on the island of San Pietro (Carloforte, Sud Sardegna). It remains to be ascertained if the majority of the former records of Chasmanthe aethiopica (L.) N.E.Br., presently considered invasive in Sardegna, should be referred to C. floribunda.

G. Sotgiu Cocco, M. Marignani, S. Bardi, L. Rosati

\section{Cistus $\times$ purpureus Lam. nothosusbp. purpureus (Cistaceae)}

+ (CAS) ITALIA (PUG): Brindisi (Brindisi), loc. Punta Penne (WGS84: 40.683468 ${ }^{\circ}$, 17.935878 E), su suoli sabbiosi, 5 m, 12 May 2018, V. Tomaselli (FI, Herb. V. Tomaselli). - Casual alien nothospecies new for the flora of Italy (Puglia). 
This widely cultivated taxon was identified according to Sweet (1825-1830) and was found in garrigues with Thymbra capitata (L.) Cav. and Poterium spinosum L., on sandy soils, in Habitat of Community Interest code 5420 "Sarcopoterium spinosum phryganas".

V. Tomaselli, R.P. Wagensommer

\section{Colocasia esculenta (L.) Schott (Araceae)}

+ (CAS) SIC: Messina (Messina), fraz. Santo Stefano Medio (WGS84: $38.106583^{\circ} \mathrm{N}$, $15.488588^{\circ} \mathrm{E}$ ), lungo un canale ai margini di coltivi, $95 \mathrm{~m}, 27$ February 2020, F. Luchino (FI). - Casual alien species confirmed for the flora of Sicilia.

Giardina et al. (2007), on the basis of historical records, indicated this species for several localities in Sicilia. Many individuals were found along a canal used for irrigation and for conveying rainwater, on the edge of several cultivated fields. The plants are distributed in small groups of 1-10 individuals, over a distance of $200 \mathrm{~m}$, in a partially shaded environment. A second small population was observed a decade ago in western Sicilia, along the Frattina stream near Corleone (Palermo), several hundred kilometres away from the above locality, in similar environments.

F. Luchino, O. Caldarella, A. La Rosa

\section{Cotoneaster bullatus Bois (Rosaceae)}

+ (NAT) ITALIA (LOM): Rovetta (Bergamo), Val Bielone, bosco presso Via del Lò (WGS84: $45.893956^{\circ} \mathrm{N}, 9.977416^{\circ} \mathrm{E}$ ), bosco di latifoglie, $674 \mathrm{~m}$, SSW, 1 September 2019, G. Galasso (MSNM No. 50690); ibidem (WGS84: $45.893214^{\circ} \mathrm{N}, 9.976903^{\circ} \mathrm{E}$ ), bosco di latifoglie, $663 \mathrm{~m}$, SSW, 1 September 2019, G. Galasso (FI, MSNM No. 50693); ibidem (WGS84: $45.893214^{\circ} \mathrm{N}, 9.976903^{\circ} \mathrm{E}$ ), bosco di latifoglie, $663 \mathrm{~m}$, SSW, 28 June 2020, G. Galasso (FI, MSNM Nos. 50694, 50695). - Naturalized alien species new for the flora of Italy (Lombardia).

This species was identified according to Fryer and Hylmö (2009), Dickoré and Kasperek (2010), and Stace (2010). Native to China, it presents bullate leaves, 3.5$9.0 \mathrm{~cm}$ long, with 6-9 very deeply impressed veins. Several dozen individuals fruit abundantly and occupy about $13,000 \mathrm{~m}^{2}$.

G. Galasso, E. Banfi

\section{Cotoneaster divaricatus Rehder \& E.H.Wilson (Rosaceae)}

+ (CAS) ITALIA (LOM): Rovetta (Bergamo), Val Bielone, Via del Lò, verso il fondo, sulla sinistra (WGS84: $45.897723^{\circ} \mathrm{N}, 9.978366^{\circ} \mathrm{E}$ ), margine stradale, $726 \mathrm{~m}, \mathrm{E}$, 22 July 2019, leg. et det. G. Galasso, conf. A.N. Sennikov (FI, MSNM No. 50672); ibidem, Val Bielone, bosco presso Via del Lò (WGS84: $45.894927^{\circ} \mathrm{N}, 9.978532^{\circ} \mathrm{E}$ ), bosco di latifoglie, $668 \mathrm{~m}$, SSW, 14 October 2020, leg. G. Galasso, det. A.N. Sennikov (FI, MSNM No. 50846). - Casual alien species new for the flora of Italy (Lombardia).

This species was identified according to Fryer and Hylmö (2009), Dickoré and Kasperek (2010), and Stace (2010). Native to China, it differs from 
Cotoneaster horizontalis Decne. in leaves $1.0-3.0 \mathrm{~cm}$ long and $0.7-1.9 \mathrm{~cm}$ wide (vs $0.5-1.2 \times 0.5-0.9 \mathrm{~cm})$, and branches never forming regular herring-bone pattern, and from $C$. simonsii Baker in leaves to $2.5 \mathrm{~cm}$ long $(v s 3.5 \mathrm{~cm})$, \pm lanceolate-ovate to ovaterhombic ( $v s$ ovate to oblong) with 3-4 veins lightly impressed ( vs 4-5 not impressed). Two plants were observed, one of which fruits regularly.

$$
\text { G. Galasso, E. Banfi, A.N. Sennikov }
$$

\section{Cotoneaster franchetii Bois (Rosaceae)}

+ (INV) ITALIA (LOM): Rovetta (Bergamo), Val Bielone, bosco presso Via del Lò (WGS84: $45.893850^{\circ} \mathrm{N}, 9.976254^{\circ} \mathrm{E}$ ), bosco di latifoglie, $660 \mathrm{~m}$, SSW, 22 July 2019 , leg. et det. G. Galasso, conf. A.N. Sennikov (FI, MSNM Nos. 50670, 50671); ibidem (WGS84: $45.895240^{\circ} \mathrm{N}, 9.978740^{\circ} \mathrm{E}$ ), bosco di latifoglie, $695 \mathrm{~m}$, SSW, 1 September 2019, leg. et det. G. Galasso, conf. A.N. Sennikov (MSNM Nos. 50683, 50684); ibidem (WGS84: $45.895171^{\circ} \mathrm{N}, 9.978434^{\circ} \mathrm{E}$ ), bosco di latifoglie, $695 \mathrm{~m}$, SSW, 1 September 2019, leg. et det. G. Galasso, conf. A.N. Sennikov (FI, MSNM No. 50686); ibidem (WGS84: $45.894274^{\circ} \mathrm{N}, 9.977392^{\circ} \mathrm{E}$ ), bosco di latifoglie, $678 \mathrm{~m}$, SSW, 1 September 2019, leg. et det. G. Galasso, conf. A.N. Sennikov (FI, MSNM Nos. 50688, 50689); ibidem (WGS84: $45.893569^{\circ} \mathrm{N}, 9.976769^{\circ} \mathrm{E}$ ), bosco di latifoglie, $666 \mathrm{~m}$, SSW, 1 September 2019, leg. et det. G. Galasso, conf. A.N. Sennikov (FI, MSNM No. 50692); ibidem (WGS84: $45.893463^{\circ} \mathrm{N}, 9.976788^{\circ} \mathrm{E}$ ), bosco di latifoglie, $665 \mathrm{~m}, \mathrm{SSW}, 28$ June 2020, leg. et det. G. Galasso, conf. A.N. Sennikov (FI, MSNM Nos. 50696, 50697, 50698); ibidem (WGS84: $45.895701^{\circ} \mathrm{N}, 9.978775^{\circ} \mathrm{E}$ ), bosco di latifoglie, $700 \mathrm{~m}, \mathrm{~W}$, 28 June 2020, leg. et det. G. Galasso, conf. A.N. Sennikov (FI, APP, MSNM Nos. 50706, 50707, 50708); ibidem (WGS84: $45.893887^{\circ} \mathrm{N}, 9.976804^{\circ} \mathrm{E}$ ), bosco di latifoglie, 668 m, SSW, 14 October 2020, leg. et det. G. Galasso, conf. A.N. Sennikov (FI, MSNM Nos. 50842, 50843). - Status change from casual to invasive alien for the flora of Italy (Lombardia).

The species was recently recorded as casual alien in Lombardia by Mauri (2020). It presents (Fryer and Hylmö 2009; Dickoré and Kasperek 2010; Stace 2010) ovate to elliptic leaves, to $4 \mathrm{~cm}$ long, with 3-5 impressed veins, silevery tomentose underside. It can be mistaken for Cotoneaster pannosus Franch., with patent instead of erect petals. According to Dickoré and Kasperek (2010), and Tison and de Foucault (2014), we consider C. mairei H.Lév. as a synonym of $C$. franchetii. Several hundred individuals fruit abundantly and occupy the entire undergrowth of about $33,000 \mathrm{~m}^{2}$, and also grow up along the mountainside.

G. Galasso, E. Banfi, A.N. Sennikov

\section{Cotoneaster horizontalis Decne. (Rosaceae)}

+ (CAS) PIE: Giaglione (Torino), bassa Val Clarea, in prossimità del cavalcavia dell'autostrada A32 del Frejus (WGS84: $45.130574^{\circ} \mathrm{N}, 6.990841^{\circ} \mathrm{E}$ ), radura in bosco di latifoglie, 680 m, 29 May 2020, M. Lonati, D. Barberis, M. Pittarello (FI). - Casual alien species new for the flora of Piemonte. 
Some young individuals were found growing near the Clarea creek, in the understory of a young broadleaf forest.

M. Lonati, D. Barberis, M. Pittarello

+ (INV) ITALIA (LOM): Rovetta (Bergamo), Val Bielone, bosco presso Via del Lò (WGS84: $45.893850^{\circ} \mathrm{N}, 9.976254^{\circ} \mathrm{E}$ ), bosco di latifoglie, $660 \mathrm{~m}, \mathrm{SSW}, 22$ July 2019, G. Galasso (MSNM No. 50669); ibidem (WGS84: $45.895171^{\circ} \mathrm{N}, 9.978434^{\circ} \mathrm{E}$ ), bosco di latifoglie, 695 m, SSW, 1 September 2019, G. Galasso (FI, MSNM No. 50687); Fino del Monte (Bergamo), Val di Bi, sentiero tra Masù e la Cappelletta degli Alpini (WGS84: $45.898205^{\circ} \mathrm{N}, 9.998142^{\circ} \mathrm{E}$ ), bosco di latifoglie, $768 \mathrm{~m}$, SE, 5 September 2020, G. Galasso (FI, MSNM No. 50811); ibidem, Val di Bi, strada forestale poco oltre la Cappelletta degli Alpini (WGS84: $45.903189^{\circ} \mathrm{N}, 9.997746^{\circ} \mathrm{E}$ ), bosco di latifoglie, 910 m, W, 5 September 2020, G. Galasso (FI, MSNM No. 50816). - Status change from naturalized to invasive alien for the flora of Italy (Lombardia).

In Rovetta, several hundred individuals fruit abundantly and occupy the entire undergrowth of an area of about $33,000 \mathrm{~m}^{2}$; they also grow up along the mountainside.

G. Galasso, E. Banfi

\section{Cotoneaster simonsii Baker (Rosaceae)}

+ (NAT) LOM: Sirtori (Lecco), loc. Cascina Giuditta, presso Via G. Besana (WGS84: $45.737215^{\circ} \mathrm{N}, 9.342631^{\circ} \mathrm{E}$ ), margine di sentiero boschivo, $520 \mathrm{~m}$, NE, 7 September 2016, leg. M. Villa, det. A.N. Sennikov (FI); ibidem, 7 November 2016 (MSNM No. 48298); ibidem, 29 May 2017 (MSNM No. 48299); Rovetta (Bergamo), Val Bielone, bosco presso Via del Lò (WGS84: $45.895171^{\circ} \mathrm{N}, 9.978434^{\circ} \mathrm{E}$ ), bosco di latifoglie, 695 m, SSW, 1 September 2019, leg. G. Galasso, det. G. Galasso, E. Banfi (FI, MSNM No. 50685); ibidem (WGS84: $45.895167^{\circ} \mathrm{N}, 9.978475^{\circ} \mathrm{E}$ ), bosco di latifoglie, $695 \mathrm{~m}$, SSW, 28 June 2020, leg. G. Galasso, det. G. Galasso, E. Banfi (MSNM No. 50699); ibidem (WGS84: $45.895455^{\circ} \mathrm{N}, 9.978239^{\circ} \mathrm{E}$ ), bosco di latifoglie, $712 \mathrm{~m}$, SSW, 28 June 2020, leg. G. Galasso, det. G. Galasso, E. Banfi (FI, MSNM No. 50705); ibidem, 14 October 2020, leg. G. Galasso, det. G. Galasso, E. Banfi (FI, MSNM No. 50836). Status change from casual to naturalized alien for the flora of Lombardia.

This species was recently recorded as casual alien in Lombardia by Villa (2020). It presents ovate to broadly elliptic leaves, deciduous or semi-evergreen, 1.9-3.3 cm long, with 4-5 not impressed veins, sparsely strigose, with flat margins (Fryer and Hylmö 2009; Dickoré and Kasperek 2010; Stace 2010; Fryer and Zika 2014). In Sirtori, only one individual occours, while in Rovetta there are a few plants scattered over about $20,000 \mathrm{~m}^{2}$ of woodland, some regularly fruiting.

M. Villa, E. Banfi, G. Galasso, A.N. Sennikov

+ (CAS) TAA: Stenico (Trento), c/o fraz. Seo, loc. Fratte (WGS84: 46.056010 N, $\left.10.866876^{\circ} \mathrm{E}\right)$, scarpata presso alcune villlette, $850 \mathrm{~m}, \mathrm{~S}, 2$ December 2017, leg. $M$. Merli, det. G. Galasso, conf. A.N. Sennikov (Herb. M. Merli); ibidem, 22 November 
2018 (Herb. M. Merli); ibidem, 23 November 2018 (FI, MSNM No. 50847); ibidem, 8 June 2020 (Herb. M. Merli); ibidem, 10 June 2020 (FI, MSNM No. 50848, ROV). - Casual alien species new for the flora of Trentino-Alto Adige.

Only one individual was observed.

M. Merli, E. Banfi, G. Galasso, A.N.Sennikov

\section{Cotula australis (Sieber ex Spreng.) Hook.f. (Asteraceae)}

+ (NAT) LAZ: Roma (Roma), Via del Mascherino 30 (WGS84: $41.903479^{\circ} \mathrm{N}$, $12.458651^{\circ} \mathrm{E}$ ), selciato a blocchetti di leucitite (sanpietrini), ca. $19 \mathrm{~m}, 10$ April 2021, R. Guarino (FI, MSNM Nos. 50880, 50881). - Status change from casual to naturalized alien for the flora of Lazio.

The first record for Lazio of this species (Lucchese 2017) was for a casual presence on the lakeshore of Trevignano Romano (Roma), at about $33 \mathrm{~km} \mathrm{NW}$ from the current finding. This new population grows on cobblestones paving the streets near the Vatican City (Borgo Pio). Considering that it consists of several hundred individuals scattered in multiple meta-populations, it is proposed to consider the species as naturalized in Lazio.

R. Guarino

\section{Cotula coronopifolia L. (Asteraceae)}

+ (NAT) MAR: Porto Recanati (Macerata), loc. Scossicci, stagni artificiali ad uso venatorio ("guazzi") presso la foce del Fiume Musone (WGS84: $43.4567660^{\circ} \mathrm{N}$, $13.6442480^{\circ} \mathrm{E}$ ), stagni, ca. $3 \mathrm{~m}, 29$ September 2020, N. Hofmann, S. Orlandini (FI, PESA). - Naturalized alien species new for the flora of Marche.

This species grows at the edge of artificial ponds used for hunting, where it has probably been carried by birds from neighbouring areas.

L. Gubellini, N. Hofmann, S. Orlandini

\section{Cuscuta campestris Yunck. (Convolvulaceae)}

+ (NAT) CAL: Tarsia (Cosenza), a N della diga sul Lago di Tarsia, lungo il Fiume Crati (WGS84: $39.6142582^{\circ} \mathrm{N}, 16.3064010^{\circ} \mathrm{E}$ ), su Xanthium italicum, $75 \mathrm{~m}, 28$ August 2020, L. Peruzzi (FI). - Naturalized alien species new for the flora of Calabria.

L. Peruzzi

\section{Cyclospermum leptophyllum (Pers.) Sprague ex Britton \& P.Wilson (Apiaceae)}

+ (CAS) SAR: Oristano (Oristano), presso il Vivaio Produttivo di Campulongu (WGS84: $39.961387^{\circ} \mathrm{N}, 8.600895^{\circ} \mathrm{E}$ ), incolto, ruderale, infestante nella coltivazione, 6 m, 30 July 2020, leg. G. Brundu, V. Lozano, det. G. Brundu (FI, Herb. Uniss Agraria). - Casual alien species new for the flora of Sardegna. 
This species was likely introduced accidentally to Sardegna through nursery growing substrates.

G. Brundu, V. Lozano

\section{Cyperus alternifolius L. subsp. flabelliformis Kük. (Cyperaceae)}

+ (NAT) CAM: Pellezzano (Salerno), riva destra dell'Irno, sotto via F. Wenner (WGS84: $40.695469^{\circ} \mathrm{N}, 14.775396^{\circ} \mathrm{E}$ ), sponde cementificate ed inerbite, $34 \mathrm{~m}, 24$ October 2020, E. Del Guacchio (NAP, Herb. E. Del Guacchio). - Status change from casual to naturalized alien for the flora of Campania.

In Campania this taxon is widespread and propagates both vegetatively and by seed dispersal, as already noted by Del Guacchio and La Valva (2017). The new, small population regularly produces seeds and is well established.

E. Del Guacchio

\section{Cyperus esculentus L. (Cyperaceae)}

+ (NAT) UMB: Perugia (Perugia), fraz. Ponte San Giovanni, lungo le rive del Fiume Tevere (WGS84: $43.010449^{\circ} \mathrm{N}, 12.428761^{\circ} \mathrm{E}$ ), $166 \mathrm{~m}, 5$ August 2008, leg. L. Lastrucci, R. Barocco, R. Venanzoni, det. L. Lastrucci (FI barcode FI060282); Deruta (Perugia), area agricola nei pressi di Fanciullata, a margine di campo coltivato a tabacco vicino alla sponda destra del Fiume Tevere (WGS84: $42.982128^{\circ} \mathrm{N}, 12.399031^{\circ} \mathrm{E}$ ), margine di coltivo, $164 \mathrm{~m}, 23$ October 2020, F. Bonini, D. Gigante (FI, PERU-DSA3). - Naturalized alien species confirmed for the flora of Umbria.

In Umbria, a plant community dominated by Cyperus esculentus was previously mentioned by Lastrucci et al. (2012b), but the status of this species has never been specified. Both new stands consist of many individuals of different generations, probably originated by vegetative reproduction given the conspicuous presence of tubers, and covering in one case an area of $c a .1,500 \mathrm{~m}^{2}$.

F. Bonini, D. Gigante, L. Lastrucci

\section{Cyperus schweinitzii Torr. (Cyperaceae)}

+ (NAT) VEN: Verona (Verona), stazione ferroviaria di Verona Porta Nuova, sulla massicciata (WGS84: $45.42530201^{\circ} \mathrm{N}, 10.96320326^{\circ} \mathrm{E}$ ), massicciata ferroviaria, 67 m, 17 September 2020, A. Bertolli, F. Prosser (FI, ROV No. 74209); ibidem, stazione ferroviaria di Verona Porta Vescovo, sulla massicciata (WGS84: $\left.45.43345724^{\circ} \mathrm{N}, 11.01062515^{\circ} \mathrm{E}\right)$, massicciata ferroviaria, $58 \mathrm{~m}, 17$ September 2020, A. Bertolli, F. Prosser (ROV No. 74210). - Naturalized alien species new for the flora of Veneto.

This species grows and settles on stabilized pebbly embankments, often naked due to weeding. In the Porta Nuova railway station, there are $c a .100$ plants distributed in three groups growing in the train maintenance sector over a stretch of $c a .150 \mathrm{~m}$. In the Porta Vescovo station, there are about 100 plants in several groups in the freight yard 
over a stretch of $c a .700 \mathrm{~m}$. A subsequent survey carried out in all the other railway stations in the province of Verona gave negative results.

A. Bertolli, F. Prosser

\section{Dimorphotheca ecklonis DC. (Asteraceae)}

+ (CAS) SAR: Selargius (Cagliari), loc. San Lussorio, lungo il sentiero che percorre la zona umida (WGS84: 39.261238º, $9.155397^{\circ} \mathrm{E}$ ), $9 \mathrm{~m}, 12$ May 2020, G. Bacchetta, M. Fois (FI, CAG); Santa Giusta (Oristano), loc. Pauli sa Figu, presso la stra-

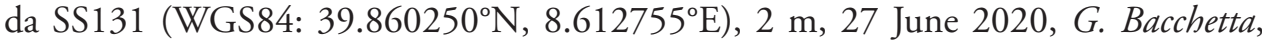
M. Fois (CAG); Villasimius (Sud Sardegna), loc. Simius, lungo la spiaggia (WGS84: $\left.39.124728^{\circ} \mathrm{N}, 9.526095^{\circ} \mathrm{E}\right), 2$ m, 15 September 2020, G. Bacchetta, A. Lallai, L. Podda (CAG). - Casual alien species new for the flora of Sardegna.

The observed individuals of this species probably originated from plants cultivated as ornamentals in nearby gardens or established from dumped garden cuttings.

G. Bacchetta, M. Fois, A. Lallai, L. Podda

\section{Dysphania pumilio (R.Br.) Mosyakin \& Clemants (Amaranthaceae)}

+ (NAT) LIG: Pietra Ligure (Savona), Via Don G. Bado, lungomare, presso il deposito delle barche (WGS84: $44.148011^{\circ} \mathrm{N}, 8.283063^{\circ} \mathrm{E}$ ), pavimentazione stradale con mattonelle, 3 m, no exp., 23 August 2020, G. Galasso (FI, MSNM No. 50834); ibidem, Via Don G. Bado, lungomare, presso il locale "Blue Bay" (WGS84: 44.148344 N, $8.283942^{\circ} \mathrm{E}$ ), pavimentazione stradale con mattonelle, $5 \mathrm{~m}$, no exp., 23 August 2020, G. Galasso (FI, MSNM No. 50835); ibidem, Via Don G. Bado, lungomare (WGS84: $\left.44.148627^{\circ} \mathrm{N}, 8.284586^{\circ} \mathrm{E}\right)$, pavimentazione stradale con mattonelle, $5 \mathrm{~m}$, no exp., 24 August 2020, G. Galasso (FI). - Naturalized alien species new for the flora of Liguria.

G. Galasso

\section{Elsholtzia stauntonii Benth. (Lamiaceae)}

+ (CAS) ITALIA (TAA): Trento (Trento), argine sinistro del Torrente Fersina in loc. Ghiaie (WGS84: $46.047903^{\circ} \mathrm{N}, 11.119232^{\circ} \mathrm{E}$ ), scarpata cespugliata, $195 \mathrm{~m}, 19$ September 2020, leg. M. Merli, det. F. Verloove (FI, MSNM No. 50849, ROV, Herb. M. Merli). - Casual alien species new for the flora of Italy (Trentino-Alto Adige).

We observed two flowering bushes of this ornamental Chinese species, identified according to Whiteley (2000).

M. Merli, F. Prosser, F. Verloove

\section{Eragrostis frankii (Fisch., C.A.Mey. \& Avé-Lall.) Steud. (Poaceae)}

+ (CAS) SIC: Catania (Catania) (WGS84: 37.509255N, 15.088711E), lungo il bordo strada, 13 m, 31 December 2018, leg. S. Brullo, det. E. Banfi, G. Galasso (FI, CAT).Casual alien species new for the flora of Sicilia. 
Several individuals grow in a small area of the city centre of Catania along roadsides. G. Tavilla, S. Cambria

\section{Erigeron annuus (L.) Desf. subsp. lilacinus Sennikov \& Kurtto (Asteraceae)}

+ (NAT) ITALIA (PIE): Verrua Savoia (Torino), ruderi della Rocca, lungo il sentiero alla base delle mura (WGS84: $45.17433^{\circ} \mathrm{N}, 8.10005^{\circ} \mathrm{E} \pm 70 \mathrm{~m}$ ), incolto arido, $280 \mathrm{~m}$, 3 July 1988, leg. A. Pistarino, det. A. Sennikov December 2018 (H barcode C.411491, MRSN); Azeglio (Torino), Lago di Viverone (WGS84: $45.41175^{\circ} \mathrm{N}, 8.01931^{\circ} \mathrm{E} \pm$ $1 \mathrm{~km}$ ), margine di sentiero, $230 \mathrm{~m}, 15$ June 1992, leg. A. Pistarino, det. A. Sennikov December 2018 (H barcode C.411496, MRSN). - Naturalized alien subspecies new for the flora of Italy (Piemonte).

This taxon is very easy to recognise because of its broader, coarsely dentate leaves, long pubescence and noticeably lilac ray flowers (the ray flower colour may be rather indistinctly pale in some plants, whereas flowers in other plants in the same area may be intensely coloured). Sennikov and Kurtto (2019) observed that this taxon tends to occur close to houses and gardens, probably due to its dispersal with garden soil or other material.

A.N. Sennikov, G. Galasso

\section{Erigeron annuus (L.) Desf. subsp. strigosus (Muhl. ex Willd.) Wagenitz (Asteraceae)}

+ (NAT) ITALIA (VEN): Orgiano (Vicenza), $8 \mathrm{~km}$ SE of Lonigo on minor road from Este (WGS84: $45.35^{\circ} \mathrm{N}, 11.45^{\circ} \mathrm{E}$ ), rough ground by pool, $60 \mathrm{~m}, 1$ August 1983 , leg. J.R. Akeroyd, S.L. Jury, C.J. Miles, FJ. Rumsey 4272, det. A. Sennikov December 2018 (H barcode C.411011). - Naturalized alien subspecies new for the flora of Italy (Veneto).

The circumscription of this taxon in Sennikov and Kurtto (2019) corresponds exactly to the traditional definition given by Wagenitz (1965) in central Europe and by Tzvelev (1994) in eastern Europe. According to Frey et al. (2003), the previous records from Lombardia (Arietti and Crescini 1980; Aeschimann et al. 2004) are considered erroneous (Galasso et al. 2018) as are those from Piemonte and Veneto (Aeschimann et al. 2004). In light of these new observations, it is more appropriate to consider the presence in Lombardia and Piemonte as doubtful.

A.N. Sennikov, G. Galasso

\section{Euphorbia hypericifolia L. (Euphorbiaceae)}

+ (NAT) SAR: Quartu Sant'Elena (Cagliari), giardino privato (WGS84: $39.234936^{\circ} \mathrm{N}$, 9.176933르), 5 m, 10 July 2020, G. Campus, G. Bacchetta (FI, CAG); Decimomannu (Cagliari), loc. Bagantinus, lungo le stradine del vivaio (WGS84: $39.300743^{\circ} \mathrm{N}$, $8.970782^{\circ} \mathrm{E}$ ), stradine, $5 \mathrm{~m}, 20$ July 2020, G. Bacchetta, M. Fois, L. Podda (FI, CAG); Oristano (Oristano), presso il Vivaio Produttivo di Campulongu (WGS84: $39.961387^{\circ} \mathrm{N}, 8.600895^{\circ} \mathrm{E}$ ), incolto, ruderale, infestante nella coltivazione, $6 \mathrm{~m}, 30$ 
July 2020, leg. G. Brundu, V. Lozano, det. G. Brundu (FI, Herb. Uniss Agraria); Cagliari (Cagliari), Pirri, aiuole in Via Barracca Manna (WGS84: $39.253179^{\circ} \mathrm{N}, 9.119715^{\circ} \mathrm{E}$ ), aiuole, 48 m, 21 November 2020, G. Bacchetta, M. Fois (CAG). - Status change from casual to naturalized alien for the flora of Sardegna.

This species was reported as a casual alien for Sardegna (Mugnai et al. 2021).

G. Bacchetta, G. Brundu, G. Campus, M. Fois, V. Lozano, L. Podda

\section{Freesia leichtlinii Klatt subsp. alba (G.L.Mey.) J.C.Manning \& Goldblatt (Iridaceae)}

+ (NAT) SAR. - Status change from casual to naturalized alien for the flora of Sardegna.

A well-established, currently expanding, population was found in Stintino (Sassari, WGS84: $40.938422^{\circ} \mathrm{N}, 8.221278^{\circ} \mathrm{E}$ ). It grows within Mediterranean shrubland and along roadsides, occupying more than 9 ha, thus behaving as a spontaneous geophyte.

G. Rivieccio, C.M. Caria, S. Bagella

\section{Glandularia tenera (Spreng.) Cabrera (Verbenaceae)}

+ (CAS) SIC: Marsala (Trapani), c.da Conca (WGS84: $37.844405^{\circ} \mathrm{N}, 12.520455^{\circ} \mathrm{E}$ ), ai margini di un prato artificiale, ca. $100 \mathrm{~m}, 7$ June 2020, leg. G. Domina, det. G. Domina, G. Barone (FI, PAL). - Casual alien species new for the flora of Sicilia.

This species was identified according to O'Leary and Thode (2016).

G. Barone, E. Di Gristina, F. Scafidi

\section{Hedera hibernica (G.Kirchn.) Bean (Araliaceae)}

+ (NAT) MAR: Pesaro (Pesaro e Urbino), nei pressi del parcheggio di San Decenzio (WGS84: $43.904490^{\circ} \mathrm{N}, 12.914932^{\circ} \mathrm{E}$ ), scarpata stradale e massicciata della ferrovia, ca. 7 m, 12 November 2020, L. Gubellini (FI, PESA); ibidem, lungo la Strada dell'Angelo Custode (WGS84: $43.868528^{\circ} \mathrm{N}, 12.922919^{\circ} \mathrm{E}$ ), siepi, ca. $190 \mathrm{~m}, 25$ February 2021, L. Gubellini (PESA). - Naturalized alien species new for the flora of Marche.

This species is cultivated as ornamental and often escapes from cultivation (McAllister and Rutherford 1990). As for other alien species of Hedera, it was hitherto rather neglected.

L. Gubellini, N. Hofmann

\section{Hedera $\times$ sepulcralis R.H.Marshall \& McAll. (Araliaceae)}

+ (NAT) MAR: Falconara Marittima (Ancona), ai margini di un parcheggio lungo Via G. Marconi, al confine con il comune di Castelferretti (WGS84: $43.6129920^{\circ} \mathrm{N}$, $13.3759990^{\circ} \mathrm{E}$ ), incolto erboso, ca. $18 \mathrm{~m}, 10$ December 2020, N. Hofmann (FI, PESA). - Naturalized alien nothospecies new for the flora of Marche.

A large population of the hybrid Hedera algeriensis Hibberd $\times H$. hibernica (G.Kirchn.) Bean (Marshall et al. 2017) grows at the edge of an uncultivated field. 


\section{Hesperocyparis macrocarpa (Hartw. ex Gordon) Bartel (Cupressaceae)}

+ (CAS) ABR: Vasto (Chieti), loc. Vasto Marina, presso la strada SS16 Adriatica (WGS84: $42.083055^{\circ} \mathrm{N}, 14.741388^{\circ} \mathrm{E}$ ), margine di incolto, ca. $4 \mathrm{~m}, \mathrm{~S}, 12$ August 2020, N. Olivieri (FI). - Casual alien species new for the flora of Abruzzo.

A young individual of this species grows on the edge of an uncultivated area, on a slight slope quite close to the Adriatic Sea, on sandy soil.

N. Olivieri

\section{Hibiscus syriacus L. (Malvaceae)}

+ (CAS) CAL: Cutro (Crotone), fraz. Steccato di Cutro, strada E90 (WGS84: $38.946331^{\circ} \mathrm{N}, 16.935111^{\circ} \mathrm{E}$ ), canale di scolo delle acque piovane a bordo strada, 19 m, 25 September 2020, V.L.A. Laface, C.M. Musarella, G. Spampinato (FI, REGGIO). - Casual alien species new for the flora of Calabria.

A small group of scattered individuals was found, along with other alien species.

C.M. Musarella, V.L.A. Laface, G. Spampinato

\section{Hydrangea macrophylla (Thunb.) Ser. (Hydrangeaceae)}

+ (CAS) PIE: Cellio con Breia (Vercelli), fraz. Breia, scarpata che dalla strada SP102 scende verso il Rio Galletto (WGS84: $45.781481^{\circ} \mathrm{N}, 8.297819^{\circ} \mathrm{E}$ ), bosco misto di latifoglie, due individui, 765 m, 28 July 2019, M. Lonati, M. Probo (FI); ibidem, scarpata a valle della strada SP102 (WGS84: $45.775540^{\circ} \mathrm{N}, 8.294707^{\circ} \mathrm{E}$ ), castagneto con latifoglie miste, numerosi individui, 780 m, 28 July 2019, M. Lonati, M. Probo (FI). - Casual alien species new for the flora of Piemonte.

Both the above-mentioned populations form small stands in the undergrowth of the road slopes, both located in illegal landfills of plant material derived from private gardens. This species is frequently cultivated as ornamental in the surrounding villages and the young plants have probably originated from rooting of pruning residuals.

M. Lonati, M. Probo

\section{Lobelia erinus L. (Campanulaceae)}

+ (CAS) MAR: Amandola (Fermo), Via Roma, centro storico (WGS84: $42.9807230^{\circ} \mathrm{N}$, $\left.13.3591715^{\circ} \mathrm{E}\right)$, tra gli interstizi del selciato, $500 \mathrm{~m}, 18$ October 2020, A. Pica, J. Lupoletti (FI). - Casual alien species new for the flora of Marche.

Several mature individuals were found, probably escaped from nearby pots or flowerbeds. 


\section{Lonicera ligustrina Wall. subsp. yunnanensis (Franch.) P.S.Hsu \& H.J.Wang (Caprifoliaceae)}

+ (NAT) ITALIA (LOM): Rovetta (Bergamo), Val Bielone, bosco presso Via del Lò (WGS84: $45.894740^{\circ} \mathrm{N}, 9.978517^{\circ} \mathrm{E}$ ), bosco di latifoglie, $688 \mathrm{~m}, \mathrm{SSW}, 28$ June 2020 , G. Galasso (FI, MSNM Nos. 50700, 50701, 50702, 50703, 50704); ibidem, 14 October 2020, G. Galasso (FI, MSNM No. 50841). - Status change from casual to naturalized alien for the flora of Italy (Lombardia).

This species covers several square metres, leaning against other shrubs and forming offshoots.

G. Galasso, E. Banfi

\section{Ludwigia hexapetala (Hook. \& Arn.) Zardini, H.Y.Gu \& P.H.Raven (Onagraceae)}

+ (INV) LAZ. - Status change from naturalized to invasive alien for the flora of Lazio.

Recent investigations along the edges of Lake Bracciano revealed that, since the last report by Galasso et al. (2019), this species has colonised also the western shore, between Vicarello and Bracciano (Roma), as well as other areas (Arrone river, Anguillara Sabazia, Roma province) for a total of $c a .12 \mathrm{~km}$, showing high invasiveness both in aquatic habitats and on the beaches.

S. Magrini, E. Argenti, S. Buono

\section{Lychnis chalcedonica L. (Caryophyllaceae)}

+ (CAS) ITALIA (TAA): Santa Cristina Valgardena (Bolzano), Strada Cisles (WGS84: $46.559133^{\circ} \mathrm{N}, 11.728848^{\circ} \mathrm{E}$ ), sponde del rio a lato della strada, $1420 \mathrm{~m}, 18$ July 2019 , F. Bonali (FI, Herb. F. Bonali). - Casual alien species confirmed for the flora of Italy; casual alien species new for the flora of Trentino-Alto Adige.

Lychnis chalcedonica was reported in Italy only in the Marche as no longer recorded (Galasso et al. 2018). Some flowering individuals were observed.

F. Bonali

\section{Nassella tenuissima (Trin.) Barkworth (Poaceae)}

+ (CAS) ABR: Lanciano (Chieti), presso la strada SP82 per Treglio (WGS84: $42.224444^{\circ} \mathrm{N}, 14.401666^{\circ} \mathrm{E}$ ), area ghiaiosa, ca. $260 \mathrm{~m}, 14$ August 2020, N. Olivieri (FI). - Casual alien species new for the flora of Abruzzo.

Some individuals of different ages grow in a calcareous gravelly area with a sparse ruderal vegetation. The plants developed from seeds dispersed by the wind from individuals cultivated in flowerbeds located a few dozen metres away.

N. Olivieri 


\section{Nephrolepis cordifolia (L.) C.Presl (Nephrolepidaceae)}

+ (NAT) LIG: Pietra Ligure (Savona), Via Aurelia, presso una scalinata, sul lato del muro che guarda verso il paese (WGS84: $44.149920^{\circ} \mathrm{N}, 8.283200^{\circ} \mathrm{E}$ ), muro, $14 \mathrm{~m}$, SSE, 20 August 2019, G. Galasso (FI, MSNM Nos. 50663, 50664). - Status change from casual to naturalized alien for the flora of Liguria.

A well established, numerous population was observed.

G. Galasso

\section{Oenothera lindheimeri (Engelm. \& A.Gray) W.L.Wagner \& Hoch (Onagraceae)}

+ (CAS) MAR: Civitanova Marche (Macerata), Piazza Don E. Scorolli (Via G. Matteotti) (WGS84: $43.310663^{\circ} \mathrm{N}, 13.728768^{\circ} \mathrm{E}$ ), aiuola ai margini del parcheggio, $2 \mathrm{~m}, 7 \mathrm{Novem}-$ ber 2020, A. Pica, J. Lupoletti (FI). - Casual alien species new for the flora of Marche.

Some individuals were found in a flowerbed near the parking area.

A. Pica, J. Lupoletti

\section{Oxalis latifolia Kunth (Oxalidaceae)}

+ (NAT) LIG. - Status change from casual to naturalized alien for the flora of Liguria.

This species is widespread in the province of La Spezia and in the eastern part of the province of Genova, sometimes with quite large populations (e.g., in the Magra and Entella valleys).

D. Marchetti, D. Dagnino

\section{Phyllostachys viridiglaucescens (Carrière) Rivière \& C.Rivière (Poaceae)}

+ (NAT) MAR: Cagli (Pesaro e Urbino) (WGS84: 43.540092 ${ }^{\circ}$, $12.648702^{\circ} \mathrm{E}$ ), vegetazione ripariale, $240 \mathrm{~m}, 5$ August 2016, G. Mei (Herb. G. Mei); ibidem (WGS84: $43.541887^{\circ} \mathrm{N}, 12.652201^{\circ} \mathrm{E}$ ), area periodicamente allagata di coltivi abbandonati, 290 m, 19 May 2020, G. Mei (FI, Herb. G. Mei). - Naturalized alien species new for the flora of Marche.

G. Mei

\section{Plumbago auriculata Lam. (Plumbaginaceae)}

+ (CAS) MOL: Termoli (Campobasso), mura del borgo antico (WGS84: $42.003611^{\circ} \mathrm{N}$, $14.996944^{\circ} \mathrm{E}$ ), ca. $18 \mathrm{~m}, \mathrm{SW}, 29$ August 2020, N. Olivieri (FI). - Casual alien species new for the flora of Molise.

Some individuals of this species have settled on the upper part of the walls surrounding the old town, on a sub-vertical substrate formed by limestone and sandstone blocks, colonized mainly by Capparis spinosa $\mathrm{L}$. 


\section{Rhaphiolepis bibas (Lour.) Galasso \& Banfi (Rosaceae)}

+ (NAT) PUG: Vico del Gargano (Foggia), loc. San Nicola (WGS84: 41.916107º N, $15.948185^{\circ} \mathrm{E}$ ), incolto, $80 \mathrm{~m}, 28$ August 2020, N. Biscotti, D. Bonsanto (FI); Rodi Garganico (Foggia), loc. Canneto (WGS84: $\left.41.919412^{\circ} \mathrm{N}, 15.920386^{\circ} \mathrm{E}\right)$, agrumeto incolto, 40 m, 1 September 2020, N. Biscotti, D. Bonsanto (FI). - Naturalized alien species new for the flora of Puglia.

N. Biscotti, D. Bonsanto

\section{Rudbeckia laciniata L. (Asteraceae)}

+ (CAS) TOS: Abetone Cutigliano (Pistoia), fraz. Pian degli Ontani, appena oltre l'abitato in direzione di Pian di Novello (WGS84: $44.105877^{\circ} \mathrm{N}, 10.717935^{\circ} \mathrm{E}$ ), spontaneizzata al margine stradale, 930 m, 20 August 2020, G. Ferretti, R. Ferretti (FI). Casual alien species new for the flora of Toscana.

A single nucleus of $c a$. 10 flowering individuals was observed on the road edge, near a small mountain village. This species reproduces very efficiently by rhizome fragmentation and produces copious amounts of achenes (EPPO 2009), so careful monitoring of the population is recommended.

\section{G. Ferretti, L. Lazzaro, M. Mugnai}

\section{Rudbeckia triloba L. (Asteraceae)}

+ (CAS) LIG: Varese Ligure (La Spezia), Val di Vara, nei pressi di Cavizzano, sotto Chinela, loc. Carmelo (WGS84: $44.403376^{\circ} \mathrm{N}, 9.553931^{\circ} \mathrm{E}$ ), margine stradale, 525 m, 26 August 2020, D. Marchetti (FI); Maissana (La Spezia), strada SP523R, presso San Pietro Vara verso Varese Ligure (WGS84: $44.343645^{\circ} \mathrm{N}, 9.590019^{\circ} \mathrm{E}$ ), siepi al margine della strada, 310 m, 16 September 2020, D. Marchetti (FI, GE No. 4431). - Casual alien species new for the flora of Liguria.

This species was found in disturbed environments near the road edge.

D. Marchetti, D. Dagnino

\section{Salvia hispanica L. (Lamiaceae)}

+ (CAS) LIG: Molineri [Imperia (Imperia), Oneglia (WGS84: ca. $43.88905^{\circ} \mathrm{N}$, $8.05034^{\circ} \mathrm{E}$ ), oliveti, s.d., I. Molineri)] (BOLO-Hortus Siccus Florae Italicae barcode BOLOHSFI102871). - Casual alien species new for the flora of Liguria.

The locality, cited by Bertoloni (1833) as "Nascitur in olivetis di Oneglia in Liguria occidua. Habui a Molinerio", is the same of a previous record by Allioni (1785). These are the first records of its occurrence as a casual alien in Italy, $c a .200$ years earlier than the report from the Marche (Ballelli et al. 2015). 


\section{Setaria parviflora (Poir.) Kerguélen (Poaceae)}

+ (CAS) ABR: Montesilvano (Pescara), Riserva Naturale Pineta di Santa Filomena, presso il lungomare (WGS84: 42.505879 ${ }^{\circ} \mathrm{N}, 14.172151^{\circ} \mathrm{E}$ ), bordo strada, $2 \mathrm{~m}, 16$ August 2020, A. Stinca, F. Conti (FI, APP, PORUN-Stinca). - Casual alien species new for the flora of Abruzzo.

A. Stinca, F. Conti

\section{Tetragonia tetragonoides (Pall.) Kuntze (Aizoaceae)}

+ (NAT) SAR. - Status change from casual to naturalized alien for the flora of Sardegna.

The first records reported in the literature for Tetragonia tetragonoides in Sardegna were in the "Sassarese" and in Siddi (Viegi 1993). We observed this species as naturalized along the coastal strip of Siniscola (Nuoro), in the locality of "S'Ena e sa Chitta" (ItIsWet 2019). Like other invasive alien species, this established population is outcompeting the native coastal flora.

G. Bacchetta, M. Fois, L. Podda

\section{Tradescantia pallida (Rose) D.R.Hunt (Commelinaceae)}

+ (CAS) PUG: Castrignano del Capo (Lecce), loc. Santa Maria di Leuca, presso la strada SP358 "Delle terme salentine" (WGS84: 39.797222 $\mathrm{N}, 18.369722^{\circ} \mathrm{E}$ ), incolto, ca. $60 \mathrm{~m}$, S, 20 August 2020, N. Olivieri (FI). - Casual alien species new for the flora of Puglia.

In this site, the species grows in an uncultivated area located along the roadside, on a substrate consisting of Mediterranean red soil and limestone fragments.

N. Olivieri

\section{Vachellia karroo (Hayne) Banfi \& Galasso (Fabaceae)}

+ (INV) ITALIA (SAR). - Status change from naturalized to invasive alien for the flora of Italy (Sardegna).

This species is common throughout Sardegna, but in recent years it was recorded as spreading in the southern coastal areas (Campidano, Sarrabus-Gerrei, and SulcisIglesiente), especially at Villasimius (Sud Sardegna), near the "Stagno Santa Gilla" (Cagliari province), and at Santa Margherita di Pula (Pula, Cagliari), where it exhibits a clearly invasive behaviour, thereby threatening natural habitats.

G. Bacchetta, G. Brundu, G. Calvia, M. Fois, L. Podda

\section{Verbena brasiliensis Vell. (Verbenaceae)}

+ (CAS) MAR: Montelabbate (Pesaro e Urbino), lungo l'argine destro del Fiume Foglia (WGS84: $43.8552960^{\circ} \mathrm{N}, 12.8048870^{\circ} \mathrm{E}$ ), incolti erbosi, ca. $35 \mathrm{~m}, 28$ October 2020, F. Furlani, L. Gubellini (FI, PESA). - Casual alien species new for the flora of Marche. 
A few individuals of this species grow in an uncultivated grassland along the banks of the Foglia river.

F. Furlani, L. Gubellini

\section{Yucca gigantea Lem. (Asparagaceae)}

+ (CAS) PUG: Otranto (Lecce), strada SP87, Borgo Minerva (WGS84: $40.138597^{\circ} \mathrm{N}$, 18.494417 ${ }^{\circ}$ E), pineta, 22 m, 23 August 2019, leg. C.M. Musarella, det. V.L.A. Laface, C.M. Musarella (REGGIO); ibidem, Porto Badisco (WGS84: $40.079231^{\circ} \mathrm{N}$, 18.482242 ${ }^{\circ}$ E), bordo strada, 16 m, 23 August 2019, leg. C.M. Musarella, det. V.L.A. Laface, C.M. Musarella (FI, REGGIO); Salve (Lecce), strada SP91 Strada Litoranea (WGS84: $39.838917^{\circ} \mathrm{N}, 18.231917^{\circ} \mathrm{E}$ ), bordo strada, $12 \mathrm{~m}, 17$ August 2020, leg. V.L.A. Laface, det. V.L.A. Laface, C.M. Musarella (REGGIO); Porto Cesareo (Lecce), Spunnulate di Torre Castiglione (WGS84: 40.287500N, 17.825278E), bordo strada, 3 m, 17 August 2020, leg. V.L.A. Laface, det. V.L.A. Laface, C.M. Musarella (REGGIO); Spongano (Lecce), strada SP166 Spongano-Andrano (WGS84: $40.002800^{\circ} \mathrm{N}$, $18.372314^{\circ} \mathrm{E}$ ), bordo strada, $112 \mathrm{~m}, 18$ August 2020, leg. V.L.A. Laface, det. V.L.A. Laface, C.M. Musarella (REGGIO); Otranto (Lecce), strada SP151, Alìmini Grande (WGS84: $40.201194^{\circ} \mathrm{N}, 18.433508^{\circ} \mathrm{E}$ ), bordo strada, $23 \mathrm{~m}, 18$ August 2020, leg. V.L.A. Laface, det. V.L.A. Laface, C.M. Musarella (REGGIO). - Casual alien species new for the flora of Puglia.

C.M. Musarella, V.L.A. Laface

\section{Zantedeschia aethiopica (L.) Spreng. (Araceae)}

+ (INV) SAR. - Status change from casual to invasive alien for the flora of Sardegna. We detected several populations of Zantedeschia aethiopica colonizing wetlands and humid habitats. In particular, it is widespread along the Rio Posada (Torpè, Nuoro) with numerous lush individuals in full bloom within reed beds (28 February 2021), on the island of La Maddalena (Sassari) in the artificial lake of Puzzoni within wet meadows (10 June 2020), and in an artificial canal for facilitating freshwater runoff in the vicinity of the town of Alghero (Sassari) in the locality named Caragol (4 March 2021).

M. Marignani, E. Farris, L. Rosati

Nomenclatural and distribution updates from other literature sources

Nomenclatural, status, distribution updates, and corrections to Galasso et al. (2018) are provided in Suppl. material 1.

G. Galasso, F. Bartolucci 


\section{Acknowledgements}

We gratefully acknowledge Rizzieri R. Masin and Francesco Roma-Marzio, who provided distribution, nomenclatural and taxonomic information, Andrea S. Vega who identified Bothriochloa saccharoides subsp. saccharoides, Andrew Hipp and Anton A. Reznicek, who confirmed Carex tribuloides.

\section{References}

Aeschimann D, Lauber K, Moser DM, Theurillat J-P (2004) Flora Alpina. Haupt Verlag, Bern. Allioni C (1785) Flora Pedemontana sive enumeratio methodica stirpium indigenarum Pedemontii (Vol. 1). Excudebat Ioannes Michael Briolus R. Scientiarum Academiae impressor et bibliopola, Augustae Taurinorum.

Arietti N, Crescini A (1980) Recenti avventizie della flora bresciana. Seconda contribuzione. Natura Bresciana 16(1979): 24-51.

Arrigoni PV (2017) Flora analitica della Toscana (Vol. 2). Edizioni Polistampa, Firenze.

Baldini RM (1995) Flora vascolare del Monte Argentario (Arcipelago Toscano). Webbia 50(1): 67-191. https://doi.org/10.1080/00837792.1995.10670598

Ballelli S, Crisanti A, Lucarini D (2015) Notula: 286. In: Galasso G, Nepi C, Domina G, Peruzzi L (Eds) Notulae alla flora esotica d'Italia: 12 (244-287). Informatore Botanico Italiano 47(1): 77-90.

Barberis G, Orsino F (1984) Bothriochloa saccharoides (Sw.) Rydb. subsp. saccharoides (Graminaee), nuova per l'Italia. Webbia 37(2): 277-282. https://doi.org/10.1080/00837792.19 84.10670280

Bertoloni G (1883) Flora italica sistens plantas in Italia et in insulis circumstantibus sponte nascentes (Vol. 1(1-6)). Tipografia R. Masi, Bologna, 768 pp.

Blattner FR, Friesen N (2006) Relationship between Chinese chive (Allium tuberosum) and its putative progenitor A. ramosum as assessed by random amplified polymorphic DNA (RAPD). In: Zeder MA, Bradley DG, Emshwiller E, Smith BD (Eds) Documenting domestication: new genetic and archaeological paradigms. California University Press, Berkeley, Los Angeles, London, 134-142. https://doi.org/10.1525/9780520932425-013

de Vos MP (1985) Revision of the South African genus Chasmanthe (Iridaceae). South African Journal of Botany 51(4): 253-261. https://doi.org/10.1016/S0254-6299(16)31654-4

Del Guacchio E, La Valva V (2017) The non-native vascular flora of Campania (southern Italy). Plant Biosystems 152(4): 767-779. https://doi.org/10.1080/11263504.2017.1338626

Dickoré WB, Kasperek G (2010) Species of Cotoneaster (Rosaceae, Maloideae) indigenous to, naturalising or commonly cultivated in Central Europe. Willdenowia 40(1): 13-45. https://doi.org/10.3372/wi.40.40102

EPPO (2009) The situation of Rudbeckia laciniata in the EPPO region. EPPO Reporting Service no. 02-2009, Num. article: 2009/040. https://gd.eppo.int/reporting/article-128 [accessed 09.04.2021]

Frey D, Baltisberger M, Edwards PJ (2003) Cytology of Erigeron annuus s.l. and its consequences in Europe. Botanica Helvetica 113(1): 1-14. https://doi.org/10.5169/seals-74395 
Fryer J, Hylmö B (2009) Cotoneasters. A comprehensive guide to shrubs for flowers, fruit, and foliage. Timber Press, Portland, London.

Fryer J, Zika PF (2014) The typification of Cotoneaster symondsii (Rosaceae). Phytotaxa 164(2): 149-153. https://doi.org/10.11646/phytotaxa.164.2.9

Galasso G, Conti F, Peruzzi L, Ardenghi NMG, Banfi E, Celesti-Grapow L, Albano A, Alessandrini A, Bacchetta G, Ballelli S, Bandini Mazzanti M, Barberis G, Bernardo L, Blasi C, Bouvet D, Bovio M, Cecchi L, Del Guacchio E, Domina G, Fascetti S, Gallo L, Gubellini L, Guiggi A, Iamonico D, Iberite M, Jiménez-Mejías P, Lattanzi E, Marchetti D, Martinetto E, Masin RR, Medagli P, Passalacqua NG, Peccenini S, Pennesi R, Pierini B, Podda L, Poldini L, Prosser F, Raimondo FM, Roma-Marzio F, Rosati L, Santangelo A, Scoppola A, Scortegagna S, Selvaggi A, Selvi F, Soldano A, Stinca A, Wagensommer RP, Wilhalm T, Bartolucci F (2018) An updated checklist of the vascular flora alien to Italy. Plant Biosystems 152(3): 556-592. https://doi.org/10.1080/11263504.2018.1441197

Galasso G, Domina G, Adorni M, Ardenghi NMG, Banfi E, Bedini G, Bertolli A, Brundu G, Calbi M, Cecchi L, Cibei C, D’Antraccoli M, De Bastiani A, Faggi G, Ghillani L, Iberite M, Latini M, Lazzeri V, Liguori P, Marhold K, Masin R, Mauri S, Mereu G, Nicolella G, Olivieri N, Peccenini S, Perrino EV, Peruzzi L, Petraglia A, Pierini B, Prosser F, RomaMarzio F, Romani R, Sammartino F, Selvaggi A, Signorile G, Stinca A, Verloove F, Nepi C (2016) Notulae to the Italian alien vascular flora: 1. Italian Botanist 1: 17-37. https://doi. org/10.3897/italianbotanist.1.8777

Galasso G, Domina G, Andreatta S, Angiolini C, Ardenghi NMG, Aristarchi C, Arnoul M, Azzella MM, Bacchetta G, Bartolucci F, Bodino S, Bommartini G, Bonari G, Buono S, Buono V, Caldarella O, Calvia G, Corti E, D’Antraccoli M, De Luca R, De Mattia F, Di Natale S, Di Turi A, Esposito A, Ferretti G, Fiaschi T, Fogu MC, Forte L, Frigerio J, Gubellini L, Guzzetti L, Hofmann N, Laface VLA, Laghetti G, Lallai A, La Rosa A, Lazzaro L, Lodetti S, Lonati M, Luchino F, Magrini S, Mainetti A, Marignani M, Maruca G, Medagli P, Mei G, Menini F, Mezzasalma V, Misuri A, Mossini S, Mugnai M, Musarella CM, Nota G, Olivieri N, Padula A, Pascale M, Pasquini F, Peruzzi L, Picella G, Pinzani L, Pirani S, Pittarello M, Podda L, Ravetto Enri S, Rifici CD, Roma-Marzio F, Romano R, Rosati L, Scafidi F, Scarici E, Scarici M, Spampinato G, Stinca A, Wagensommer RP, Zanoni G, Nepi C (2019) Notulae to the Italian alien vascular flora: 8. Italian Botanist 8: 63-93. https://doi.org/10.3897/italianbotanist.8.48621.suppl1

Giardina G, Raimondo FM, Spadaro V (2007) A catalogue of plants growing in Sicily. Bocconea 20: 5-582.

Grandis M (2016) Sulla presenza di Chasmanthe floribunda e Chasmanthe aethiopica in Italia. Acta Plantarum Notes 4: 137-139.

ItIsWet [Italian Islands Wetlands] (2019) ITG26SAR2741 - Foce di s'Ena sa Chitta. Updated: 06.2020. https://italiaiswet.it/general/report.php?id=2487\&lang=en [accessed 20.11.2020]

Lambinon J (1995) Corrections et commentaires apportés aux exsiccata distribués dans les fascicules précédents: $n^{\circ} 8930$ [17] - Dichanthium saccharoides. Bulletin. Société pour l'Échange des Plantes Vasculaires de l'Europe et du Bassin Méditerranéen 25: 19.

Lastrucci L, Calamassi R, Ferretti G, Galasso G, Foggi B (2012a) Contributo alla conoscenza della flora esotica dell'Isola di Capraia (Arcipelago Toscano, Italia). Atti della Società 
Italiana di Scienze Naturali e del Museo Civico di Storia Naturale di Milano 153(1): 127_ 134. https://doi.org/10.4081/nhs.2012.127

Lastrucci L, Landucci F, Gonnelli V, Barocco R, Foggi B, Venanzoni R (2012b) The vegetation of the upper and middle River Tiber (Central Italy). Plant Sociology 49(2): 29-48. https:// doi.org/10.7338/pls2012492/02

Lazzaro L, Ferretti G, Giuliani C, Foggi B (2014) A checklist of the alien flora of the Tuscan Archipelago (Italy). Webbia 69(1): 157-176. https://doi.org/10.1080/00837792.2014.907981

Lazzeri V (2016) Note floristiche tosco-sarde III: novità per le regioni Toscana e Sardegna. Quaderni del Museo di Storia Naturale di Livorno 25(2013-2014): 67-77.

Li X-w, Hedge IC (1994) Lamiaceae. In: Wu ZY, Raven PH (Eds) Flora of China (Vol. 17). Science Press, Beijing, Missouri Botanical Garden Press, St. Louis, 50-299.

Lu D, Gilbert MG (2003) Nyctaginaceae. In: Wu ZY, Raven PH, Hong DY (Eds) Flora of China (Vol. 5). Science Press, Beijing, Missouri Botanical Garden Press, St. Louis, 430-434.

Lucchese F (2017) Atlante della flora alloctona del Lazio: cartografia, ecologia e biogeografia. Vol. 1: Parte generale e flora alloctona. Regione Lazio, Direzione Ambiente e Sistemi Naturali, Roma.

Marshall RH, McAllister HA, Armitage JD (2017) A summary of hybrids detected in the genus Hedera (Araliaceae) with the provision of three new names. New Journal of Botany 7(1): 2-8. https://doi.org/10.1080/20423489.2017.1344041

Mastrogiuseppe J, Rothrock PE, Dibble AC, Reznicek AA (2002) Carex Linnaeus sect. Ovales Kunth. In: Flora of North America Editorial Committee (Ed.) Flora of North America North of Mexico (Vol. 23). Oxford University Press, New York, Oxford, 477-482.

Mauri ES (2020) Noterella 0276: Cotoneaster franchetii Bois. Acta Plantarum Notes 7: 260.

McAllister HA, Rutherford A (1990) Hedera helix L. and H. hibernica (Kirchner) Bean (Araliaceae) in the British Isles. Watsonia 18(1): 7-15.

Mugnai M, Lazzaro L, Di Nuzzo L, Foggi B, Viciani D, Ferretti G (2021) Synopsis of Euphorbia section Anisophyllum (Euphorbiaceae) in Italy, with an insight on variation of distribution over time in Tuscany. Phytotaxa 485(1): 1-65. https://doi.org/10.11646/phytotaxa.485.1.1

Nicolella G (2018) Noterella 0205. Amaranthus muricatus (Moq.) Gillies ex Hieron. Acta Plantarum Notes 6: 151.

O'Leary N, Thode V (2016) The genus Glandularia (Verbenaceae) in Brazil. Annals of the Missouri Botanical Garden 101(4): 699-749. https://doi.org/10.3417/2014008

Sennikov AN, Kurtto A (2019) The taxonomy and invasion status assessment of Erigeron annuus s.l. (Asteraceae) in East Fennoscandia. Memoranda Societatis pro Fauna et Flora Fennica 95: 40-59.

Sommier S (1900) Aggiunte alla flora dell'Elba. Bullettino della Società Botanica Italiana 1900(6): 204-212.

Stace CA (2010) New flora of the British Isles (Ed. 3.). Cambridge University Press, Cambridge. Sweet R (1825-1830) Cistineæ. The natural order of Cistus, or rock-rose; illustrated by coloured figures \& descriptions of all the distinct species, and the most prominent varieties, that could be at present procured in the gardens of Great Britain; with the best directions for their cultivation and propagation. James Ridgway, London. Re-printed in 2017 by Forgotten Books. https://doi.org/10.5962/bhl.title.20402 
Tison J-M, de Foucault B [Eds] (2014) Flora gallica. Flore de France. Biotope, Mèze.

Tzvelev NN (1994) Phalacroloma Cass. In: Tzvelev NN (Ed.) Flora of the European part of the USSR (Vol. 7). Science Publishers, St. Petersburg, 203-204. [In Russian]

Udulutsch RG, Sá CFC, Rossetto EFS, Cidrão BB (2020) Bougainvillea. In: Flora do Brasil 2020. Jardim Botânico do Rio de Janeiro. http://floradobrasil.jbrj.gov.br/reflora/floradobrasil/FB10905 [accessed 15.04. 2021]

Vega AS (2000) Taxonomic revision of the North and South American species of the genus Bothriochloa (Poaceae: Panicoideae: Andropogoneae). Darwiniana 38(1-2): 127-186.

Verloove F, Ardenghi NMG (2015) New distributional records of non-native vascular plants in northern Italy. Natural History Sciences 2(1): 5-14. https://doi.org/10.4081/nhs.2015.219

Verloove F, Lambinon J (2008) Deux graminées introduites peut-être méconnues, nouvelles pour la flore française: Bothriochloa laguroides et Dichanthelium acuminatum subsp. linheimeri (Poaceae: Panicoideae). Le Monde des Plantes 497: 1-4.

Viegi L (1993) Contributo alla conoscenza della biologia delle infestanti delle colture della Sardegna nord-occidentale: censimento delle specie esotiche della Sardegna. Bollettino della Società Sarda di Scienze Naturali 29: 131-234.

Villa M (2020) Noterella 0277: Cotoneaster simonsii Baker. Acta Plantarum Notes 7: 261.

Wagenitz G (1965) Compositae (cont.). In: Hegi G (Ed.) Illustrierte Flora von Mitteleuropa ((Ed. 2), Vol. 6/3(2)). C. Hanser, München, 81-160.

Wallnöfer B, Essl F (2016) Overview on alien Carex species of section Cyperoideae (including Ovales) in Europe and the discovery of Carex scoparia in Austria. Annalen des Naturhistorischen Museums in Wien, Serie B 118: 115-127.

Whiteley AC (2000) Elsholtzia Willdenow. In: Cullen J, Alexander JCM, Brickell CD, Edmondson JR, Green PS, Heywood VH, Jørgensen P-M, Jury SL, Knees SG, Maxwell HS, Miller DM, Robson NKB, Walters SM, Yeo PF (Eds) The European garden flora. A manual for the identification of plants cultivated in Europe, both out-of-doors and under glass (Vol. 6). Cambridge University Press, Cambridge, 227-228.

\section{Supplementary material I}

\section{Supplementary data}

Authors: Gabriele Galasso, Fabrizio Bartolucci

Data type: Species data

Explanation note: 1. Nomenclatural updates; 2. Note updates; 3. Distribution updates; 4. Synonyms, misapplied or included names.

Copyright notice: This dataset is made available under the Open Database License (http://opendatacommons.org/licenses/odbl/1.0/). The Open Database License $(\mathrm{ODbL})$ is a license agreement intended to allow users to freely share, modify, and use this Dataset while maintaining this same freedom for others, provided that the original source and author(s) are credited.

Link: https://doi.org/10.3897/italianbotanist.11.68063.suppl1 